Volume 1, Nomor 2, September 2019, pp 14-25. Copyright (C 2019 JAFTA, Program Studi Magister Akuntansi, Fakultas Ekonomi, Universitas Kristen Maranatha. ISSN: 2654-4636| E-ISSN: 2656-758X https://journal.maranatha.edu/index.php/jafta

\title{
Sudahkah Dana Sekolah Dikelola Dengan Baik?
}

\author{
Oleh: \\ Aprina Nugrahesthy Sulistya Hapsari \\ Fakultas Ekonomika dan Bisnis \\ Program Studi Akuntansi Universitas Kristen Satya Wacana \\ email: esthy@staff.uksw.edu \\ Dally Wahyu Seta \\ Fakultas Ekonomika dan Bisnis \\ Program Studi Akuntansi Universitas Kristen Satya Wacana \\ email: 232015124@student.uksw.edu
}

\begin{abstract}
ABSTRAK
Penelitian ini bertujuan untuk menganalisis penerapan tata kelola yang baik di Sekolah X. Sekolah adalah lembaga nirlaba di bidang pendidikan yang tidak terpisahkan dari risiko kecurangan dalam pengelolaan dana sekolah. Kecurangan di sektor pendidikan dapat diminimalisir dengan adanya penerapan prinsip-prinsip tata kelola yang baik di sekolah. Penelitian ini menggunakan pendekatan deskriptif kualitatif dengan menggunakan wawancara sebagai teknik pengumpulan datanya. Narasumber dalam penelitian ini adalah Sekretaris Sekolah, Kepala Sekolah, Departemen Keuangan, Murid dan Wali Murid. Hasil penelitian menunjukkan bahwa penerapan prinsip-prinsip tata kelola yang baik masih belum optimal diterapkan dalam pengelolaan dana di Sekolah X. Hal ini dikarenakan masih minimnya aturan tertulis, khususnya terkait kebijakan dari pimpinan sekolah.
\end{abstract}

Kata kunci: Tata Kelola, Nirlaba, Dana Sekolah

\section{ABSTRACT}

This study aims to analyze the application of good governance in School X. Schools are non-profit institutions in the field of education that are inseparable from the risk of fraud in the management of school funds. Fraud in the education sector can be minimized by the application of the principles of good governance in schools. This study uses a qualitative descriptive approach using interviews as a data collection technique. The informans in this study were the School Secretary, Principal, Ministry of Finance, Students and Parents. The results of the study indicate that the application of the principles of good governance is still not optimally applied in the management of funds in School X. This is due to the lack of written rules, especially related to the policies of school leaders.

Keywords: Governance; Non Profit; School Fund

\section{Pendahuluan}

Revolusi industri 4.0 mengguncang dunia pendidikan, yang ditunjukkan dengan perkembangan teknologi secara masif dan mulai menggeser segala sesuatu yang bersifat konvensional atau pola pendidikan yang lama (Harususilo 2018). Konsep revolusi industri 4.0 menekankan pada integrasi antara objek fisik, manusia, kecerdasan mesin, jalur produksi dan proses yang membentuk suatu sistem (Hozdić 2015). Hal tersebut menuntut perubahan besar, termasuk pendidikan pada jenjang pendidikan dasar dan menengah. Pendidikan di era revolusi industri 4.0 merupakan pendidikan yang bercirikan pemanfaatan teknologi digital dalam proses pembelajaran. Pendidikan yang diimbangi dengan karakter dan literasi akan menjadikan murid menjadi bijak dalam menggunakan teknologi untuk kepentingan masyarakat (Darmawan 2018).

Seiring dengan perkembangan dunia pendidikan di era revolusi industri 4.0 ini pula kemudian juga membawa dampak terhadap tata kelola yang baik. Dalam mewujudkan tata kelola yang baik 
perlu pemanfaatan teknologi, sebaliknya pemanfaatan teknologi perlu diimbangi dengan tata kelola yang baik untuk menjamin bahwa tujuan organisasi dapat tercapai (Wulandari 2019). Secara teori dalam organisasi, tata kelola yang baik merupakan sebuah konsep yang mengelola dan mengawasi pola hubungan antar pemangku kepentingan dalam perusahaan, yaitu hubungan antara manajemen dan stakeholder. Konsep tata kelola yang baik ini dapat mewujudkan tatanan yang lebih baik untuk membantu melindungi pihak yang saling berkepentingan dalam mengatasi setiap konflik kepentingan yang mungkin muncul dalam kehidupan berorganisasi (Retno M. \& Priantinah, 2012). Konsep tata kelola yang baik yang dijelaskan oleh Komite Nasional Kebijakan Governance (2006) yang menekankan pada pengelolaan perusahaan berdasarkan lima dasar yaitu Transparancy, Accountability, Responsibility, Independency dan Fairness. Implementasi konsep tata kelola yang baik dalam organisasi dapat dilihat melalui peran pengendalian internal yang diterapkan dalam perusahaan tersebut serta sinergi manajemen tingkat atas dalam mengelola kebijakan bagi organisasi.

Fenomena tata kelola Indonesia di kancah dunia ditunjukkan dengan adanya peningkatan ratarata skor ASEAN Corporate Governance Indonesia pada tahun 2012 - 2015, seperti yang terlihat dalam Tabel 1. Kondisi tersebut memberi arti bahwa dalam hal implementasi tata kelola di Indonesia telah secara konsisten mengalami peningkatan.

\section{Tabel 1. Indonesia - Corporate Governance Scores, 2012 - 2015}

\begin{tabular}{lcccc} 
& $\mathbf{2 0 1 2}$ & $\mathbf{2 0 1 3}$ & $\mathbf{2 0 1 4}$ & $\mathbf{2 0 1 5}$ \\
\hline $\begin{array}{l}\text { Skor } \\
\text { Terendah }\end{array}$ & 20.81 & 31.40 & 31.24 & 36.27 \\
\hline $\begin{array}{l}\text { Skor Rata- } \\
\text { rata }\end{array}$ & 43.26 & 54.95 & 57.27 & 62.68 \\
\hline $\begin{array}{l}\text { Skor } \\
\text { Tertinggi }\end{array}$ & 73.36 & 84.39 & 91.98 & 103.15 \\
\hline
\end{tabular}

kelola yang baik memang sering dihubungkan dengan organisasi atau perusahaan yang berorientasi profit, seperti penelitian yang dilakukan oleh Iswara (2014) yang mengambil objek penelitian pada perusahaan yang terdaftar di Bursa Efek Jakarta dengan hasil bahwa manajemen perusahaan belum tertarik terhadap manfaat penerapan Good Corporate Governance (GCG) dalam jangka panjang, sehingga merasa dapat berjalan tanpa penerapan GCG tersebut. Penelitian lain terkait dengan penerapan tata kelola yang baik dilakukan juga di PT. Pos Indonesia (Persero) dikaitkan dengan pelaksanaan sistem informasi akuntansi. Hasil yang diperoleh menunjukkan bahwa pelaksanaan GCG di PT. Pos Indonesia (Persero) telah diterapkan secara memadai (Halimatusadiah \& Gunwan, 2014). Implementasi GCG tidak dapat dilihat hanya oleh kacamata organisasi profit saja, melainkan juga perlu melihat dari perspektif organisasi nirlaba. Beberapa penelitian yang menunjukkan dampak penerapan tata kelola yang baik pada organisasi nirlaba adalah Azlina dan Amelia (2014) menjelaskan bahwa penerapan tata kelola yang baik berdampak positif dan berbanding lurus dengan penerimaan wakaf tunai organisasi pengelola wakaf di Indonesia. Selain itu hasil yang senada ditunjukkan dalam penelitian yang dilakukan oleh Yuliafitri dan Rivaldi (2017) yang menunjukkan bahwa penerapan tata kelola yang semakin baik di lingkungan pemerintah kabupaten, maka akan meningkatkan pula kinerja pemerintahan kabupaten tersebut. Sedangkan Sektiono dan Nugraheni (2017) memberikan hasil penelitian berupa implementasi prinsip tata kelola yang baik pada organisasi nirlaba akan mendorong pertumbuhan organisasi dan meningkatkan kepercayaan organisasi di mata publik.

Sekolah merupakan sebuah organisasi sektor pendidikan yang juga tidak terhindar dari paparan potensi penyimpangan atau penyalahgunaan wewenang. Perkembangan global yang saat ini semakin mempermudah segala sesuatu, semestinya mampu mendukung penerapan kelima prinsip dasar 
tata kelola yang baik dalam meminimalkan potensi penyimpangan atau penyalahgunaan wewenang terutama di sekolah. Hasil pemetaan tindak korupsi yang dilakukan oleh Indonesia Corruption Watch (2018) mencatat bahwa selama tahun 2018 terdapat 11 kasus korupsi di sekolah dengan kerugian negara mencapai Rp7,5 miliar dengan mayoritas pelaku adalah kepala sekolah. Beberapa kasus saat ini yang terjadi di lingkungan sekolah, diantaranya penyalahgunaan wewenang atas pengelolaan dana BOS oleh mantan kepala SMAN 3 Depok yang merugikan negara Rp349.790.000,00 (Poskotanews 2019), kasus serupa yang juga terjadi di SMAN 1 Pelaihari Banjarmasin yang menimbulkan kerugian negara mencapai Rp576.131.780,00 berdasarkan perhitungan BPKP Kalimantan Selatan (Harian Umum Kalsel Pos 2019) dan kasus korupsi dana BOS oleh Kepala SMKN 2 Kisaran dengan dana yang dikorupsi mencapai Rp900 juta. Ketiga kasus tersebut menggambarkan bahwa sekolah sebagai organisasi di sektor pendidikan pun belum mampu sepenuhnya menerapkan konsep GCG.

Berdasarkan latar belakang tersebut, penelitian ini bermaksud untuk melakukan analisis penerapan prinsip-prinsip tata kelola yang baik di Sekolah X. Penelitian dengan objek Sekolah X menarik dilakukan, karena sekolah ini merupakan sekolah swasta di Jawa Tengah yang memiliki garis pertanggungjawaban keuangan kepada universitas. Sekolah ini juga merupakan sekolah penerima dana Bantuan Operasional Sekolah (BOS) dari pemerintah dengan jumlah peserta didik lebih dari 400 siswa dan guru berjumlah 30 orang pada Tahun Ajaran 2017/2018. Penelitian ini pada akhirnya dapat bermanfaat secara praktis bagi sekolah sebagai bahan evaluasi atas penerapan tata kelola di sekolah terhadap pengelolaan dana BOS. Secara teoritis penelitian ini juga diharapkan dapat bermanfaat bagi akademisi dalam menambah literatur mengenai penerapan tata kelola yang baik.

\section{Tinjauan Teori}

\section{Tata Kelola Organisasi yang Baik (Good Corporate Governance)}

Kemunculan prinsip good corporate governance (GCG) didasari oleh mega skandal perusahaan publik seperti Enron dan Worldcom yang merupakan hasil dari kegagalan stakeholder dalam melakukan pengawasan terhadap top level management sehingga menyebabkan praktek kecurangan berlangsung dalam jangka waktu lama. Rumor terkait tata kelola di Indonesia sendiri muncul seiring dengan berakhirnya Orde Baru di tahun 1998, di mana seluruh jenjang tatanan masyarakat dituntut untuk melakukan perubahan yang lebih baik dari sisi pemerintah maupun dari sisi masyarakat. Prinsip GCG menurut Komite Cadbury bertindak sebagai pengatur perusahaan dalam menyelaraskan otoritas dan kekuatan perusahaan sebagai bentuk responsibilitas terhadap stakeholder (Dewi \& Widagdo, 2012), sedangkan menurut Perum Perumnas (2016) tata kelola perusahaan yang baik merupakan suatu aktivitas peningkatan akuntabilitas dalam upaya meningkatkan keberhasilan perusahaan untuk menambah nilai bagi pemilik dengan berdasarkan peraturan dan nilai etika yang ada. Konsep GCG menitikberatkan pada dua hal, pertama, pentingnya pemenuhan hak pemegang saham melalui pemberian informasi yang relevan dan tepat waktu. Kedua, pemenuhan kewajiban perusahaan dalam mengungkapkan semua informasi terkait perusahaan, kepemilikan dan stakeholder dengn akurat, tepat waktu dan transparan (Kaihatu , 2006).

Komite Nasional Kebijakan Governance (2006) menjelaskan bahwa terdapat lima asas tata kelola yang baik yang dibutuhkan dalam perturutan usaha dengan tetap melihat stakeholder sebagai pemangku kepentingan, yaitu pertama, asas transparansi. Asas ini mengedepankan objektivitas bisnis dengan pengungkapan informasi yang relevan 
JAFTA — Vol. 1 Nomor 2, September (2019)

dan sesuai dengan peraturan yang ada bagi pengambilan keputusan oleh pemangku kepentingan. Pengungkapan informasi juga menjadi fokus di organisasi non profit seperti sekolah. Sekolah sebagai lembaga penyedia layanan publik bagi masyarakat dituntut untuk terbuka. Kedua, pengelolaan usaha yang dilakukan dengan transparan, terukur dan sejalan dengan nilai-nilai perusahaan harus bisa dibuktikan dalam bentuk pertanggungjawaban kepada manajemen dan pemegang saham merupakan prinsip dasar asas akuntabilitas. Ketiga, asas responsibilitas mengatur perusahaan untuk mematuhi peraturanperaturan yang telah ditetapkan oleh pemerintah berdasarkan prinsip kehati-hatian dan melaksanakan tanggungjawab sosial terhadap masyarakat dan lingkungan. Keempat, asas independensi sebagai salah satu komponen dalam penerapan prinsip good corporate governance menitikberatkan pada pengelolaan perusahaan secara independen di antara organ-organ yang ada untuk menghindari dominasi salah satu pihak yang dapat mempengaruhi hasil pengambilan keputusan. Kelima, dalam pelaksanaan aktivitas perusahaan, perusahaan dituntut untuk mampu menyeimbangkan antara kepentingan manajemen dan pemegang saham sebagai bentuk implementasi asas kewajaran dan kesetaraan dalam kaitannya dengan penerapan tata kelola perusahaan yang baik. Belum adanya konsep pasti yang menjelaskan mengenai penerapan prinsip tata kelola yang baik pada organisasi nirlaba, sehingga penelitian ini mengadopsi kelima prinsip tersebut untuk dianalisis penerapannya di organisasi sekolah.

\section{Organisasi Nirlaba}

Tinungki dan Pusung (2014) mengartikan organisasi nirlaba sebagai sebuah entitas sosial yang pengorganisasiannya dilakukan oleh lebih dari satu orang dengan batasan yang jelas dalam mencapai tujuan bersama. Sebagai social entity, Dianti dan Suprayogi (2018) menjelaskan bahwa aktiva yang diperoleh organisasi nirlaba dari kegiatan bisnisnya tidak dibagikan kepada direksi maupun anggota organisasi, akan tetapi organisasi berhak untuk memenuhi kewajibannya kepada karyawan berupa gaji atau upah. Sementara organisasi nirlaba yang efektif mencari kepentingan yang seimbang antara tujuan organisasi dengan harapan dan aspirasi anggotanya dengan mengkomunikasikan tujuan sosial mereka kepada publik (Jo \& Yoo, 2015). Organisasi nirlaba yang umum di masyarakat ada di berbagai sektor, seperti organisasi keagamaan, organisasi pendidikan, organisasi bantuan masyarakat, organisasi asosiasi profesional maupun organisasi yang bergerak di bidang politik. Sehingga dapat disimpulkan bahwa organisasi nirlaba merupakan himpunan sosial yang menjalankan kegiatannya sebagai bentuk sosial kepada masyarakat berdasarkan pada kondisi sosial dan tujuan organisasi. Penelitian ini pun lebih berfokus pada organisasi disektor pendidikan yaitu sekolah sebagai objeknya.

\section{Metode Penelitian}

\section{Jenis Penelitian dan Teknik Pengumpulan Data}

Penelitian ini merupakan penelitian deskriptif kualitatif dengan objek penelitian dilakukan di salah satu sekolah swasta di Jawa Tengah yang didukung oleh 30 orang pendidik dengan jumlah peserta didik lebih dari 400 siswa pada Tahun Ajaran 2017/2018. Penelitian ini akan menganalisis penerapan tata kelola di sekolah tersebut berdasarkan fenomena saat ini mengenai penyelewengan dana Bantuan Operasional Sekolah yang marak terjadi. Data yang digunakan dalam penelitian ini menggunakan data primer yang diperoleh dari kegiatan wawancara dan dokumentasi. Narasumber dalam penelitian ini adalah sekretaris direktur sekolah, kepala sekolah dan orang tua/wali siswa. Informasi yang akan diolah untuk mendukung penelitian ini berdasarkan data primer yang diperoleh 
JAFTA — Vol. 1 Nomor 2, September (2019)

dari informan dengan metoda wawancara dan dokumentasi.

\section{Teknik Analisis Data}

Miles dan Huberman (1994) menjelaskan bahwa penelitian dengan data kualitatif memiliki tiga jalur kegiatan analisis data. Teknik analisis data yang pertama adalah melakukan reduksi data. Reduksi data dari hasil wawancara digunakan untuk menyortir data mentah yang sifatnya masih umum dan luas menjadi data yang lebih sederhana dan mudah dipahami. Hasil reduksi data berupa informasi yang sederhana tersebut selanjutnya dilakukan verifikasi terkait orisinalitas data tersebut dengan melakukan perbandingan dari sudut pandang yang berbeda. Tahap selanjutnya adalah penyajian data dari informasi yang telah diverifikasi. Penyajian data yang dilakukan memungkinkan untuk menarik sebuah kesimpulan yang selanjutnya menjadi dasar dalam melakukan tindakan. Setelah melakukan pengumpulan dan menganalisis data, barulah di tahap terakhir adalah menarik kesimpulan. Kesimpulan yang akan dipetik dari penelitian ini adalah penerapan tata kelola yang baik di sekolah $\mathrm{X}$ dilihat dari pengelolaan dana sekolah.

\section{Hasil Penelitian dan Pembahasan}

\section{Gambaran Objek Penelitian}

Sekolah X merupakan sebuah lembaga pendidikan swasta yang berada di Jawa Tengah yang menyelenggarakan pendidikan mulai dari pendidikan usia dini hingga pendidikan menengah atas. Pemikiran awal dalam pendirian sekolah ini adalah sebagai wadah bagi mahasiswa program pendidikan di sebuah universitas melakukan praktik pengajaran. Sekolah ini pada mulanya berdiri di bawah naungan sebuah yayasan yang juga menaungi sebuah universitas, hingga akhirnya kedudukan sekolah tersebut beralih menjadi di bawah universitas tersebut.
Perpindahan kedudukan tersebut selanjutnya diikuti dengan perubahan pola pelaporan kegiatan pendidikan yang semula kepala sekolah di setiap jenjang bertanggungjawab kepada ketua yayasan, menjadi dipertanggungjawabkan kepada rektor universitas.

Sekolah X sebagai organisasi non profit dalam memberikan pelayanan di sektor pendidikan tidak terlepas dari dukungan sisi pendanaannya. Pendanaan di sektor pendidikan sendiri merupakan tanggungjawab bersama antara masyarakat, pemerintah daerah dan pemerintah pusat, sesuai dengan pasal 2 Peraturan Pemerintah Nomor 48 Tahun 2008 tentang Pendanaan Pendidikan. Umumnya penyelenggaraan pendidikan yang berkualitas, terdapat pendanaan yang besar dibaliknya. Dalam melaksanakan program pendidikan, Sekolah $\mathrm{X}$ bergantung pada pendanaan secara rutin yang bersumber dari peserta didik berupa Sumbangan Pembinaan Pendidikan (SPP) dan sumbangan Bantuan Operasional Sekolah (BOS) dari Kementerian Pendidikan. Sumber pendanaan kedua yang lebih secara temporer adalah pendanaan yang berasal dari Pemerintah Provinsi atau Kabupaten/Kota, sehingga pengelolaan yang baik terhadap dana pendidikan diperlukan agar dana sekolah dapat digunakan secara tepat dan efisien dalam pemenuhan jangka pendek maupun jangka panjang sekolah.

\section{Transparansi di Dalam Pengelolaan Dana Sekolah}

Prinsip pertama dalam penerapan tata kelola yang baik adalah transparansi. Transparansi merupakan suatu bentuk timbal balik antara organisasi dengan pihak eksternal atau publik melalui keterbukaan informasi organisasi. Praktik transparansi Sekolah X dilihat dari pengelolaan dana pendidikan di sekolah tersebut baik pengelolaan dana pembinaan pendidikan maupun dana Bantuan Operasional Sekolah (BOS). Sekolah X masih mengungkapkan realisasi penggunaan dana BOS dan dana pembinaan 
JAFTA — Vol. 1 Nomor 2, September (2019)

pendidikan yang diperoleh secara terbatas. Hasil wawancara dengan Ibu FI selaku sekretaris direktur sekolah menyatakan bahwa belum sepenuhnya realiasi penggunaan dana sekolah dalam hal ini penggunaan dana BOS secara transparan. Sebagian besar pengelolaannya hanya diketahui oleh internal sekolah.

"Kalau realisasi penggunaan dana sekolah atau dana BOS ya mas, kita nggak membuat kaya MMT tentang realisasi penggunaannya biar bisa diliat umum gitu, enggak. Kami hanya menjelaskan penggunaanya ke orang tua/wali garis besarnya aja mas waktu ada pertemuan dengan orang tua. Kita dapet dana BOS untuk periode ini besarnya segini, terus dana BOS ini tujuannya untuk apa. Yaa sebatas itu aja mas."

Berbeda dengan dana BOS yang merupakan dana bantuan dari pemerintah, dana pendidikan sekolah yang berasal dari pembayaran SPP setiap siswa dan peruntukkannya bagi kegiatan siswa dan biaya penunjang pendidikan tidak sepenuhnya diungkapkan kepada publik karena menyangkut informasi sensitif internal sekolah.

"SPP itu didalemnya ada dua komponen mas, BPP sama biaya kegiatan. Kalau BPP itu ya untuk nggaji guru dan karyawan gitu, tapi kalau yang biaya kegiatan ya untuk mendanai kegiatan siswa. Misalnya kegiatan valentine, atau study tour untuk kelas 1,2,3. Kan kalau yang kelas 1 sama 3 biasanya ke Jogja terus yang kelas 2 kan ke Bali. Nah uangnya diambil dari biaya kegiatan itu. Kami hanya menjelaskan komponen dari SPP nya itu sendiri. Nggak sedetail sampai seberapa besar yang diterima tiap bulannya terus pengeluarannya buat apa, nggak sampai segitunya."

Informasi senada diperoleh dari salah satu orang tua/wali yang mengatakan bahwa masih minimnya informasi terkait dana bantuan yang diperoleh sekolah $\mathrm{X}$ dan realisasi penggunaannya. Begitu pula dengan dana sekolah yang rutin dibayarkan oleh siswa setiap bulannya, orang tua/wali hanya mengetahui besaran nominalnya dan penggunaan dana tersebut secara umum saja.

"wah ning swasta masalah BOS aku rasane ra tau dijelaske ek mas, wong nek ada pertemuan orang tua/wali ki paling pas jipuk rapor. Sing terakhir ki pas meh study tour kae. Nek pas jipuk rapot paling yo mung dikandani masalah akademik anake piye,nek ra nek ono kurangkurang bayar. Nek sing pertemuan orang tua terakhir ki sekolah njelaske meh ono study tour, makane orang tua arep ditariki dana gedhe. Yo ngono kui mas. “

Di sekolah swasta masalah BOS saya merasa tidak pernah dijelaskan, kalau ada pertemuan orang tua/wali itu saja saat ambil rapor. Yang terakhir waktu mau study tour. Kalau watu ambil rapor hanya diberitahu masalah akademik anaknya gimana, kalau tidak ketika ada kurang-kurang bayar. Kalau yang pertemuan orang tua terakhir, sekolah menjelaskan bahwa akan ada kegiatan study tour, sehingga orang tua akan dimintai dana besar.

"Penggunaan SPP aku yo ra ngerti mas, ngertine yen bayar enem atus seket kui di enggo kegiatan-kegiatan misa, trus study tour mau, trus fotocopy materi yo ngono kui."

Penggunaan SPP saya juga tidak tahu, tahunya hanya bayat enam ratus lima puluh di pakai untuk kegiatan-kegiatan misa, kemudian study tour, lalu fotocopy materi, ya begitu.

Hasil wawancara tersebut menunjukkan bahwa Sekolah X belum sepenuhnya menjalankan prinsip transparansi dalam pengelolaan dana sekolah. Rencana anggaran dan realisasi anggaran terkait penggunaan kedua sumber pendanaan sekolah 
tersebut belum sepenuhnya dapat diketahui oleh warga sekolah atau pihak-pihak yang membutuhkan informasi tersebut.

\section{Akuntabilitas di Dalam Pengelolaan Dana Sekolah}

Prinsip kedua dalam penerapan tata kelola organisasi yang baik adalah dilihat dari akuntabilitas organisasi. Akuntabilitas dalam pengelolaan dana sekolah merupakan bentuk pertanggungjawaban penggunaan dana yang telah diperoleh, baik dana sekolah yang dipertanggungjawabkan kepada rektor maupun pertanggungjawaban dana BOS kepada Dinas Pendidikan. Hal tersebut senada dengan yang dijelaskan oleh Ibu FI.

“Kalau pertanggungjawaban kami terkait penggunaan dana BOS, kami bertanggungjawab langsung ke pemerintah mas. Untuk laporan BOS mesti dibutuhkan oleh dinas terkait untuk mengalokasi dana BOS periode berikutnya. Dari laporan yang kita buat itu juga buat bahan evaluasi penggunaan BOS pemerintah. Sedangkan untuk pertanggungjawaban realisasi dana sekolah langsung ke universitas. Kalau laporan dana sekolah untuk rektor ambil keputusan investasi. Terus ada audit dari BOS yang hasilnya normal."

Bentuk pertanggungjawaban Sekolah X atas penggunaan dana sekolah yang bersumber dari siswa didik adalah dengan melaporkan seluruh kegiatan yang sumber pendanaannya dari dana sekolah. Realisasi penggunaan dana sekolah selanjutnya di laporkan kepada universitas. Berdasarkan audit yang telah dilakukan terhadap Sekolah X sebagai bagian dari unit universitas, menunjukkan bahwa terdapat celah yang ditimbulkan akibat informasi yang ada tidak mencerminkan informasi yang ada. Hal tersebut dibuktikan dengan hasil audit terhadap sekolah tersebut yang menyatakan bahwa saldo piutang sekolah tidak sama dengan kondisi yang sebenarnya.
Pernyataan tersebut sesuai dengan yang disampaikan oleh auditor internal sekolah.

"Yang kami temukan itu kurangnya transparansi sekolah sehingga berpengaruh pada penyajian piutang sekolah yang tidak sesuai dengan laporan yang disajikan.'

Hal ini dapat disimpulkan bahwa prinsip akuntabilitas Sekolah X kurang terpenuhi dari sisi pengelolaan dana internal sekolah. Akan tetapi dari sisi pengelolaan dana BOS yang dipertanggungjawabkan kepada pemerintah, prinsip akuntabilitas Sekolah X terpenuhi. Hasil pemeriksaan dari pemerintah mengenai penggunaan dana bantuan operasional, Sekolah X telah menggunakannya sesuai dengan peruntukannya seperti yang telah diatur dalam Permendikbud Nomor 3 Tahun 2019 mengenai petunjuk teknis bantuan operasional sekolah reguler. Sampai saat ini pun sekolah X masih mendapat kepercayaan dari pemerintah untuk mengelola dana bantuan dari pemerintah.

\section{Responsibilitas di Dalam Pengelolaan Dana Sekolah}

Penerapan tata kelola yang baik juga harus didukung dengan kualitas tanggungjawab organisasi. Sekolah sebagai lembaga sektor pendidikan yang memberikan layanan pendidikan kepada masyarakat harus mampu mempertanggunggjawabkan alokasi dana sekolah kepada pihak yang berkepentingan dalam bentuk laporan keuangan. Untuk pertanggungjawaban penggunaan dana BOS harus dilaporkan melalui mekanisme yang telah ditetapkan pemerintah. Bentuk pelaporan dilakukan dengan menggunakan sistem informasi yang juga telah disyaratkan oleh pemerintah. Hal ini berdampak pada kewajiban yang mau tidak mau harus dipenuhi oleh pihak sekolah dalam kaitannya dengan tanggungjawab pembuatan laporan keuangan. Hal ini 
JAFTA — Vol. 1 Nomor 2, September (2019)

sesuai yang disampaikan oleh Ibu Ad selaku bendahara BOS.

"Kalau dana BOS udah jelas dari pemerintah, aplikasi sudah ada, jadi pihak sekolah wajib melaporkan tiap periode yang ditentukan. Kalau terlambat, ya paling buruk dana BOSnya bisa dihentikan dari pemerintah."

Sama halnya untuk tanggungjawab pembuatan laporan keuangan dana internal sekolah, pihak sekolah juga wajib membuat laporan keuangan sesuai dengan aturan yang ditetapkan oleh universitas sebagai pemegang kewenangan atas pertanggungjawaban sekolah. Karena laporan keuangan akhir sekolah disusun oleh universitas, maka pihak universitas juga tidak menerima adanya keterlambatan dalam pelaporan keuangan. Ibu Ad menjelaskan demikian.

"Sekolah kita kan posisinya di bawah universitas, jadi kewajiban penyusunan laporan keuangan akhir di susun oleh universitas. Jadi kalau dari pihak kami belum memperbarui salah satu akuan, universitas pasti nagih-nagih. Kalau dana BOS udah jelas mas dari pemerintah, aplikasi sudah ada, jadi pihak sekolah wajib melaporkan tiap periode yang ditentukan. Kalau terlambat, ya paling buruk dana BOS-nya bisa dipotong atau dihentikan dari pemerintah."

Pertanggunggjawaban alokasi pendanaan sekolah $\mathrm{X}$ dilihat dari tingkat kesesuaian realisasi pendanaan sekolah dengan peraturan atau prosedur yang telah ditetapkan sekolah atau kesesuaian secara hukum. Secara umum realisasi dana sekolah harus sesuai dengan perencanaan dana sekolah. Alokasi dana pendidikan di Sekolah X masih ditemukan kegiatan yang sebenarnya tidak dianggarkan di awal oleh sekolah, namun tetap diselenggarakan. Salah satunya adalah kegiatan gathering guru dan karyawan yang diadakan oleh sekolah $\mathrm{X}$, dimana kegiatan tersebut bagi kepala sekolah merupakan kegiatan dalam rangka mengapresiasi kinerja pendidik, tenaga pendidik dan karyawan di sekolah X. Dalam penganggaran sekolah $\mathrm{X}$ di awal periode tersebut tidak terncantum rencana kegiatan gathering tersebut. Akan tetapi pada akhirnya kegiatan tersebut tetap terlaksana menggunakan dana yang bersumber dari selisih lebih realisasi pendanaan kegiatan-kegiatan yang telah terlaksana.

"Kita pernah ada kegiatan yang diperintahkan oleh kepala sekolah untuk bikin acara kumpul keluarga besar sekolah Mas. Karena diawal kita tidak menganggarkan sehinggakegiatan itu dananya kita ambil dari kelebihan dana dari kegiatan yang sudah jalan mas."

Berdasarkan data yang telah dijelaskan, dapat ditarik kesimpulan bahwa penerapan tata kelola yang baik di Sekolah X belum optimal. Penilaian tersebut berdasarkan pertanggungjawaban Sekolah $\mathrm{X}$ yang kurang optimal.

\section{Independensi Di Dalam Pengelolaan Dana Sekolah} Independensi dalam lembaga pendidikan seperti Sekolah X dapat dilihat dari peran pimpinan dalam mengatur dan mengelola organisasi. Independensi sekolah berfokus pada upaya meminimalkan adanya konflik kepentingan antara pimpinan dengan pihak-pihak lain. Peran direktur sebagai pimpinan tertinggi Sekolah $\mathrm{X}$ masih belum nampak. Kebijakan dana BOS, investasi dan pemanfaatan dana surplus masih dipengaruhi dan tergantung dengan pihak lain. Hal tersebut menunjukkan bahwa independensi direktur yang masih rendah. Terkait hal tersebut, Ibu FI selaku sekretaris direktur mengatakan demikian

"Kadang kalau dimintai keputusan atau solusi masih sering meminta pertimbangan tanya

Kepala sekolah A, B, C. Jadi malah

kepentingan pihak eksternal lebih bisa mempengaruhi keputusan pihak sekolah." 
JAFTA — Vol. 1 Nomor 2, September (2019)

\section{Fairness di Dalam Pengelolaan Dana Sekolah}

Indikator penilaian tata kelola sebuah organisasi yang terakhir adalah fairness (kesetaraan). Kesetaraan yang dimaksudkan di Sekolah X adalah perlakuan yang adil terhadap penerima atau pengguna dana sekolah. Sebagai contoh dalam penyaluran dana BOS yang diberikan kepada peserta didik tidak ada mekanisme baku terkait penyaringan penerima hanya berdasarkan hasil wawancara ketika mendaftar. Tidak ada survei secara langsung mengenai kondisi calon penerima dana bantuan. Berdasarkan aturan sekolah yang menjadi prioritas sebagai penerima dana bantuan sekolah adalah siswa yang tidak mampu yang dan siswa yang berprestasi. Akan tetapi seluruh keputusan dalam penentuan penerima dana bantuan tersebut sebagian besar berada dalam kewenangan penuh Kepala Sekolah. Sehingga penyaluran dana BOS rentan disalurkan pada orang yang tidak tepat. Faktor kedekatan antara orang tua/wali siswa dengan kepala sekolah dapat mengurangi obyektivitas kepala sekolah dalam penyaluran dana sekolah sehingga prinsip keadilan diabaikan. Penilaian kelayakan sebagai penerima bantuan yang berdasarkan hasil wawancara masih mengandung subjektivitas yang tinggi, terlebih lagi tidak diikuti dengan adanya peninjauan langsung kondisi calon penerima dana bantuan di lapangan. Berdasarkan informasi tersebut terdapat temuan yang mungkin terjadi, bahwa berdasarkan hasil wawancara seorang siswa berhak memperoleh dana bantuan tersebut. Namun sesungguhnya di lapangan ditemukan hal yang bertolak belakang atau dapat dikatakan siswa tersebut sebenarnya mampu secara finansial. Hal tersebut menunjukkan masih lemahnya keadilan dalam hal penyaluran dana bantuan pendidikan. Kesimpulan tersebut didukung oleh pernyataan salah satu siswa di Sekolah X.

"Malah aku ngrasa kalau nggak pernah ditawari mau dana BOS apa nggak ik Mas",

\section{Simpulan dan Saran}

Berdasarkan hasil pembahasan dalam penelitian ini dapat diketahui bahwa Sekolah X dalam menerapkan prinsip tata kelola yang baik masih ditemukan kelemahan di setiap penerapan masingmasing prinsipnya. Berdasarkan pembahasan terkait transparansi, Sekolah X masih belum terbuka untuk mencapai good school governance. Di sisi lain penerapaan prinsip responsibilitas di Sekolah $\mathrm{X}$ sebenarnya sudah berjalan cukup baik. Akan tetapi masih ditemukannya kelemahan Sekolah X dalam menerapkan prinsip responsibilitas pada pengelolaan dana sekolah. Begitu pula dengan penerapan prinsip independensi dan fairness di Sekolah $\mathrm{X}$ yang masih belum optimal. Maka, dari kelima prinsip pengelolaan yang baik terhadap dana sekolah, menunjukkan bahwa Sekolah $\mathrm{X}$ masih belum optimal dalam mengimplementasikan semua prinsip tersebut. Penerapan tata kelola organisasi yang baik di Sekolah $\mathrm{X}$ harus memperbaiki pola kegiatan yang ada untuk memenuhi masing-masing prinsip tersebut. Kelima prinsip yang di terapkan secara optimal dapat meningkatkan penerapan tata kelola yang baik di sekolah.

Penelitian ini menganalisis penerapan tata kelola yang baik di sekolah hanya pada satu bagian kecil aktivitas saja, yaitu pada aktivitas pengelolaan dana sekolah. Penelitian ini belum terfokus pada aktivitas lainnya, sehingga penelitian ini belum bisa merepresentasikan kondisi tata kelola yang baik di sekolah secara keseluruhan. Penelitian ini tidak dapat melihat penerapan tata kelola perusahaan dari sisi laporan keuangan sekolah, karena data keuangan sekolah merupakan data sensitif sekolah sehingga informasi data keuangan sekolah yang diperoleh hanya berdasarkan pada hasil wawancara yang diperoleh. Keterbatasan lainnya tidak ada konsep yang secara spesifik menjelaskan tentang tata kelola yang baik pada sekolah, lebih banyak prinsip tata kelola mengatur pada level corporate atau perusahaan. 
JAFTA — Vol. 1 Nomor 2, September (2019)

Peneliti berikutnya dapat melihat secara menyeluruh penerapan tata kelola yang baik di organisasi. Penelitian selanjutnya juga bisa menggunakan data kuantitatif sebagai sarana analisis untuk menggambarkan tata kelola organisasi yang baik secara lebih luas.

\section{Daftar Pustaka}

Azlina, Nur, dan Ira Amelia. 2014. "Pengaruh Good Governance Dan Pengendalian Intern Terhadap Kinerja Pemerintah Kabupaten Pelalawan." Jurnal Akuntansi Universitas Jember $\quad 12 \quad$ (2): $32-42$ https://doi.org/10.19184/jauj.v12i2.1409.

Darmawan, Jon. 2018. "Menjadi Guru Era Pendidikan 4.0.” Serambinews.com. 2018 . https://aceh.tribunnews.com/2018/11/27/men jadi-guru-era-pendidikan-40.

Dewi, Retno Kusuma, dan Bambang Widagdo. 2012. "Pengaruh Corporate Social Responsibility dan Good Corporate Governance Terhadap Kinerja Perusahaan.” Jurnal Manajemen Bisnis 2 (1): 81-97.

Dianti, Dania Ulfah, dan Noven Suprayogi. 2018. "Pengelolaan Biaya Operasional LAZNAS Surabaya." Jurnal Ekonomi Syariah Teori dan Terapan 5 (8): 631-41.

Halimatusadiah, Elly, dan Bangun Gunwan. 2014. "Analisis Penerapan Good Corporate Governance Dalam Mengoplimalkan Pelaksanaan Sistem Informasi Akuntansi (Studi pada PT. Pos Indonesia (Persero))." Jurnal Riset Akuntansi Dan Keuangan 2 (1): 300-313.

https://doi.org/10.17509/jrak.v2i1.6583.

Harian Umum Kalsel Pos. 2019. “Korupsi Dana BOS Ala SMAN 1 Pelaihari.” 2019. https://kalselpos.com/2019/02/korupsi-dana- bos-ala-sman-1-pelaihari/2/.

Harususilo, Yohanes Enggar. 2018. “Ki Hadjar Dewantara dan guncangan Pendidikan Era Industri 4.0.” Kompas.com. 2018. https://edukasi.kompas.com/read/2018/05/02 /15561621/ki-hadjar-dewantara-danguncangan-pendidikan-era-industri40 ?page $=1$.

Hozdić, Elvis. 2015. "Smart Factory For Industry 4.0 : A Review" 7 (1): 28-35.

Indonesia Corruption Watch. 2018. "Tren Penindakan Korupsi 2018.” Jakarta. https://antikorupsi.org/sites/default/files/tren _korupsi_2018_0.pdf.

Iswara, Prasetyo Widyo. 2014. "Corporate Governance Dan Kinerja Perusahaan.” Jurnal Akuntansi, Ekonomi Dan Manajemen Bisnis 2 (2): 121-31.

Jo, Samsup, dan Jae-Woong Yoo. 2015. "How Does The Corporate Sector Perceive Non-Profit Organizations? Evidence From South Korea.” Journal of Communication Management $19 \quad$ (4): $\quad 324-34$. http://dx.doi.org/10.1108/095642309109785 11.

Kaihatu, Thomas S. 2006. "Good Corporate Governance dan Penerapannya di Indonesia." Jurnal Manajemen Dan $\begin{array}{lll}\text { Kewirausahaan } & 8 & \text { (1): } 1-9 .\end{array}$ https://doi.org/10.1021/bk-1991-0462.ch006.

Komite Nasional Kebijakan Governance. 2006. "Pedoman Umum Good Corporate Governance Indonesia.” Jakarta: Komite Nasional Kebijakan Governance.

Perum Perumnas. 2016. "Pedoman Good Corporate Governance." Jakarta: Perum Perumnas. 2016. https://www.perumnas.co.id/goodcorporate-governance/.

Poskotanews. 2019. "Korupsi Dana BOS, Mantan Kepsek SMAN 3 Depok Dijebloskan ke LP 
JAFTA — Vol. 1 Nomor 2, September (2019)

Sukamiskin.”

2019.

http://poskotanews.com/2019/02/20/korupsi-

dana-bos-mantan-kepsek-sman-3-depok-

dijebloskan-ke-lp-sukamiskin/.

Retno M., Reny Dyah, dan Danies Priantinah. 2012.

"Pengaruh Good Corporate Governance dan

Pengungkapan Corporate Social

Responsibility Terhadap Nilai Perusahaan

(Studi Empiris Pada Perusahaan Yang

Terdaftar Di Bursa Efek Indonesia Periode 2007-2010)." Nominal I (1): 84-103.

Sektiono, Dwi, dan Rini Nugraheni. 2017. "Implementasi Good Governance Pada Lembaga Swadaya Masyarakat (Studi Kasus Pada Aksi Cepat Tanggap Cabang Semarang)" 6 (1): 117-26. https://ejournal3.undip.ac.id/index.php/djom/ article/view/17531/16780.

Tinungki, Angelia Novrina Meilani, dan Rudy J. Pusung. 2014. "Penerapan Laporan Keuangan Organisasi Nirlaba Berdasarkan PSAK No.45 Pada Panti Sosial Tresna Werdha Hana" 2 (2): 809-19.

Wulandari, Fitri. 2019. "Wujudkan tata kelola pemerintahan yang baik, pemerintah dorong pemanfaatan teknologi." Tribunnews.com. 2019.

https://www.tribunnews.com/nasional/2019/ 03/28/wujudkan-tata-kelola-pemerintahanyang-baik-pemerintah-dorong-pemanfaatanteknologi.

Yuliafitri, Indri, dan Arie Indra Rivaldi. 2017. "Pengaruh Penerapan Prinsip-Prinsip Good Governance Dan Promosi Terhadap Penerimaan Wakaf Tunai (Pada Lembaga Pengelola Wakaf Di Indonesia)." Jurnal InFestasi $13 \quad$ (1): 217-26. http://dx.doi.org/10.21107/infestasi.v13i1.30 44.g2304. 
JAFTA — Vol. 1 Nomor 2, September (2019) 